\title{
Congenital Myotonic Dystrophy
}

National Cancer Institute

\section{Source}

National Cancer Institute. Congenital Myotonic Dystrophy. NCI Thesaurus. Code

C123308.

Myotonic dystrophy that is present at birth. 